\title{
Contribution of bone marrow-derived cells to the pro-inflammatory effects of protease-activated receptor-2 in colitis
}

\author{
Eric Hyun • Patricia Andrade-Gordon • \\ Martin Steinhoff • Paul L. Beck • Nathalie Vergnolle
}

Received: 5 November 2009/Revised: 18 January 2010/Accepted: 15 February 2010/Published online: 26 March 2010

(C) The Author(s) 2010. This article is published with open access at Springerlink.com

\begin{abstract}
Objective Our aim was to determine the contribution of proteinase-activated receptor- $2\left(\mathrm{PAR}_{2}\right)$-expressing bone marrow-derived cells on the development of colonic inflammation.

Materials Chimeric mice were generated by injecting bone marrow cells from wildtype $\left(\mathrm{PAR}_{2}^{+/+}\right)$or $\mathrm{PAR}_{2}$ knockout mice $\left(\mathrm{PAR}_{2}^{-l-}\right)$ into irradiated $\mathrm{PAR}_{2}^{+/+}$or
\end{abstract}

Responsible Editor: J. Di Battista.

Electronic supplementary material The online version of this article (doi:10.1007/s00011-010-0181-9) contains supplementary material, which is available to authorized users.

E. Hyun · P. L. Beck · N. Vergnolle

Department of Physiology and Pharmacology,

University of Calgary, 3330 Hospital Drive, Calgary,

AB T2N 4N1, Canada

P. Andrade-Gordon

Johnson \& Johnson Pharmaceutical Research \& Development,

Welsh Rd and Mckean Rd, Spring House, PA 19477, USA

\section{Steinhoff}

Department of Dermatology, Interdisciplinary Center for Clinical Research, University of Munster, Von-Esmarch-Strasse 58, 48149 Münster, Germany

\section{N. Vergnolle}

Centre de Physiopathologie de Toulouse Purpan, CHU Purpan, INSERM U563, 31000 Toulouse, France

N. Vergnolle

Université Toulouse III Paul Sabatier, route de Narbonne,

31000 Toulouse, France

N. Vergnolle $(\square)$

CHU Purpan, INSERM U563, BP 3028, 31024 Toulouse Cedex, France

e-mail: nathalie.vergnolle@inserm.fr
$\mathrm{PAR}_{2}^{-1-}$ mice. Treatments: Colitis was induced by giving $2.5 \%$ dextran sodium sulfate (DSS) solution for 7 days or by a single intracolonic administration of trinitrobenzene sulphonic acid (TNBS, $2 \mathrm{mg}$ dissolved in 40\% ethanol).

Methods Seven days after the induction of colitis, bowel thickness, inflammatory parameters [myeloperoxidase (MPO) activity, macroscopic/microscopic damage scores], and leukocyte trafficking (visualized via intravital microscopy) were assessed.

Results Total deficiency of $\mathrm{PAR}_{2}$ resulted in a marked reduction in severity of both TNBS and DSS induced colitis as assessed by MPO activity, macroscopic damage, bowel thickness, and leukocyte adherence. Colitis was attenuated in all chimeric lines in which there was loss of $\mathrm{PAR}_{2}$ in the host, non-bone marrow-derived tissue, independent of the status of PAR expression by bone marrowderived cells. Interestingly, TNBS colitis was attenuated in $\mathrm{PAR}_{2}^{+/+}$chimeric mice with $\mathrm{PAR}_{2}^{-1-}$ derived bone marrow but these animals were not protected from DSS colitis.

Conclusions Expression of $\mathrm{PAR}_{2}$ by host-derived tissues plays a dominant role in regulating colonic inflammation. $\mathrm{PAR}_{2}$ expression by bone marrow-derived cells appears to play a role in TNBS colitis but not in DSS induced injury.

Keywords Bone marrow .

Protease-activated receptor-2 $\left(\mathrm{PAR}_{2}\right) \cdot$ Leukocytes . Inflammation - Colitis - Inflammatory bowel disease . Chimeric murine lines

\section{Introduction}

Inflammatory bowel disease (IBD) including Crohn's disease (CD) and ulcerative colitis (UC) are chronic inflammatory conditions of the gastrointestinal tract. While 
the exact etiology of IBD is unknown, genetic, environmental and immunological factors are thought to be involved $[1,2]$.

Several studies have suggested that proteases are involved in the pathogenesis of intestinal inflammation in IBD [3-8]. These proteases including thrombin, cathepsin $\mathrm{G}$, trypsin and tryptase can modulate inflammation by cleaving and activating protease-activated receptors (PARs) [9, 10]. PARs belong to the G-protein coupled receptors (GPCR) family and are activated by a tethered ligand, which is revealed upon proteolytic cleavage of the $\mathrm{N}$-terminus domain of PARs. Synthetic peptides, PARactivating peptide (PAR-AP), with sequence analogous to the tethered ligand domain can activate PARs, in the absence of proteolytic activity. Currently, four members of the PAR family $\left(\mathrm{PAR}_{1}\right.$ to $\mathrm{PAR}_{4}$ ) have been cloned and characterized. In general, $\mathrm{PAR}_{1}$ is activated by thrombin; $\mathrm{PAR}_{2}$ is activated by trypsin and mast cell tryptase; $\mathrm{PAR}_{3}$ is activated by thrombin; and $\mathrm{PAR}_{4}$ can be activated by thrombin, trypsin, elastase, and cathepsin G [9]. Depending on the cleavage site, activation of PARs can also be prevented by proteases, through a "disarming" mechanism [11-13].

In the gastrointestinal tract, different roles for $\mathrm{PAR}_{2}$ activation have been suggested. A strong expression for $\mathrm{PAR}_{2}$ has been detected in different cell types, including epithelial cells, neurons, fibroblasts, inflammatory cells [14-18]. Several studies have also highlighted $\mathrm{PAR}_{2}$ as an important regulator of gastrointestinal functions including secretion, ion transport, permeability, motility, and sensation [19-26]. Strong evidence suggests that $\mathrm{PAR}_{2}$ is a critical mediator of colitis. In IBD patients, increased expression of $\mathrm{PAR}_{2}$ and its potential activators (trypsin and tryptase) have been observed [3, 8]. Studies have reported that local administration of $\mathrm{PAR}_{2}$-AP induced acute inflammatory response in the colon of mice [4, 27]. This inflammatory response was characterized by increased granulocyte infiltration, tissue damage/permeability and $\mathrm{T}$ helper type 1 cytokines. Further investigation indicated that $\mathrm{PAR}_{2}$-AP-induced colitis was in part mediated by the activation of neuropeptide receptors, suggesting that $\mathrm{PAR}_{2}$ activation on sensory neurons could account for these proinflammatory effects $[5,27]$. However, $\mathrm{PAR}_{2}$ agonists are also able to signal to endothelial cells and leukocytes, and have been shown to provoke severe increase in leukocyte rolling and adhesion [28]. On the other hand, systemically administered $\mathrm{PAR}_{2}$-AP has been shown to exert antiinflammatory effects in an animal model of IBD induced by trinitrobenzene sulphonic acid (TNBS) [7]. Therefore, the exact role of $\mathrm{PAR}_{2}$ in the development of colitis was uncertain and has been difficult to identify, partly because of the lack of selective $\mathrm{PAR}_{2}$ antagonists. Instead, a recent genetic approach using $\mathrm{PAR}_{2}$-deficient mice $\left(\mathrm{PAR}_{2}^{-1-}\right)$ has gained further knowledge, demonstrating that $\mathrm{PAR}_{2}^{-1-}$ mice were protected from developing colitis in three different models of IBD [TNBS, dextran sodium sulfate (DSS), and oxazolone] [29]. The degree of leukocyte trafficking and the expression of various adhesion molecules were significantly reduced in $\mathrm{PAR}_{2}^{-1-}$ mice upon colitis. These results demonstrated that in IBD models, the presence of functional $\mathrm{PAR}_{2}$ is able to control leukocyte recruitment, exerting a pro-inflammatory role. However, the cellular targets for $\mathrm{PAR}_{2}$ activation in the context of IBD remained unknown, and the question of a direct involvement of $\mathrm{PAR}_{2}$ activation on leukocytes for inflammatory cell recruitment during colitis was unsolved.

To further define the role of $\mathrm{PAR}_{2}$ in the regulation of intestinal inflammation and homeostasis, we investigated the impact of loss of $\mathrm{PAR}_{2}$ expression within bone marrow derived cells and host or recipient tissues, by constructing chimeric murine lines. Chimeric lines with normal, wildtype expression of $\mathrm{PAR}_{2}$ or targeted deletion of $\mathrm{PAR}_{2}$ that were reconstituted with $\mathrm{PAR}_{2}^{+/+}$or $\mathrm{PAR}_{2}^{-1-}$ were assessed in two differing models of colitis.

\section{Materials and methods}

\section{Animals}

Male or female $\mathrm{PAR}_{2}$-deficient mice $\left(\mathrm{PAR}_{2}^{-1-}\right)$ and wildtype littermates $\left(\mathrm{PAR}_{2}^{+/+}\right)$were originally obtained from Johnson \& Johnson Pharmaceutical Research Institute (Spring House, PA, USA), and bred at the University of Calgary in a pathogen free and temperature controlled environment. The mice were fed standard food pellets and water ad libitum. All the experimental protocols were approved by the Animal Care and Ethics Committee of the University of Calgary and conducted in accordance to the guidelines established by the Canadian Council on Animal Care.

\section{Bone marrow transplantation}

Chimeric mice were generated as previously described [30]. Briefly, donor mice $\left(\mathrm{PAR}_{2}^{-1-}\right.$ or $\left.\mathrm{PAR}_{2}^{+/+}\right)$were sacrificed via cervical dislocation and femurs and tibias were isolated. Bone marrow cells from these bones were then aspirated using a $1 \mathrm{ml}$ syringe filled with RPMI media (Invitrogen, Burlington, ON, Canada) under a sterile fume hood. Female recipient mice $\left(\mathrm{PAR}_{2}^{-1-}\right.$ or $\mathrm{PAR}_{2}^{+/+}$, 4-6 weeks old) were irradiated with two radiation doses of $500 \mathrm{rads}, 3 \mathrm{~h}$ a part, using a Gammacel $1000\left({ }^{137} \mathrm{Cs}\right.$ source, Nordion International, Kanata, ON, Canada). Immediately after the second irradiation, recipient mice were injected with $10 \times 10^{6}$ donor bone marrow cells through the tail 
vein. For the first 2 weeks after the bone marrow cell injection, chimeric mice were given neomycin sulfate $(0.2 \% \mathrm{wt} / \mathrm{vol})$ solution as a drinking water. Chimeric mice were allotted 8 weeks for bone marrow reconstitution.

Induction of colitis and study design

Colitis in chimeric mice was induced by TNBS or DSS as previously described [29]. For TNBS-induced colitis, chimeric mice were administered intracolonically with $100 \mu \mathrm{l}$ of TNBS/ethanol solution ( $2 \mathrm{mg}$ per mouse dissolved in $40 \%$ ethanol) via $1 \mathrm{ml}$ syringe fitted with a catheter. During the administration of TNBS, mice were lightly anaesthetized with halothane gas. For DSS-induced colitis, chimeric mice were given $2.5 \%$ DSS solution $(2.5 \% \mathrm{wt} / \mathrm{vol})$ as a drinking solution ad libitum for 7 days. Colitis induced by TNBS or DSS was given 7 days to develop.

The survival rate and body weight of chimeric animals were measured daily after the induction of colitis. Seven days after the induction of colitis, intravital microscopy was performed on chimeric mice. After the last reading from the intravital microscopy, chimeric mice were sacrificed via cervical dislocation and bowel thickness as well as inflammatory parameters [macroscopic/microscopic damage scores, myeloperoxidase (MPO) activity] of the colon were assessed. Bowel thickness was measured using a digital caliper (Mitutoyo, Mississauga, Canada, resolution $0.01 \mathrm{~mm})$.

\section{Intravital microscopy}

Intravital microscopy was performed on the distal colon of chimeric mice in order to visualize changes in leukocyte rolling/adherence and vessel diameter. Animals were anaesthetized with a xylazine $(10 \mathrm{mg} / \mathrm{kg}$, MTC Pharmaceuticals, Cambridge, ON, Canada) and ketamine (200 mg/kg, Rogar/STB, London, ON, Canada) mixture. Mice were also given $100 \mu \mathrm{l}$ of fluorescent dye, rhodamine 6G $(0.3 \mathrm{mg} / \mathrm{kg}$, Sigma, St. Louise, MO, USA). The dose of rhodamine $6 \mathrm{G}$ used in this study allows for visualization of leukocyte/endothelium interaction while having no effects on leukocyte kinetics [31, 32]. After mice were fully anaesthetized, a midline abdominal incision was made using a mono-polar cauterizer (Harvard apparatus, St. Laurent, QC, Canada). Segments from the distal colon were carefully exteriorized and placed on top of a viewing pedestal. The exposed colon was superfused with bicarbonate-buffered saline ( $\mathrm{pH}$ 7.4) throughout the experiment to avoid tissue dehydration. Microcirculation was observed using an inverted Olympus IX81 fluorescent microscope (Olympus, Melville, NY, USA) with $20 \times$ objective lens and visualized by epi-illumination at $510-560 \mathrm{~nm}$, using a
$590 \mathrm{~nm}$ emission filter. After 15 min of equilibration period, single venules $(20-40 \mu \mathrm{m}$ in diameter) were selected for the study.

The images of the selected venules were recorded for 5 min, which was considered as a basal reading. Additional recordings were made for $5 \mathrm{~min}$ at $10 \mathrm{~min}$ intervals for total of $80 \mathrm{~min}$. The degree of leukocyte rolling, adherence and vessel diameter were measured upon video playback. Flux of rolling leukocytes was defined as the number of leukocytes per minute moving at a velocity less than erythrocytes passing through a reference point in the venules. Leukocyte adherence was defined as stationary leukocytes on the endothelium (area of $100 \mu \mathrm{m}$ vessel length) for more than $30 \mathrm{~s}$. The change in rolling leukocytes and vessel diameter was calculated as the difference between values at each interval to basal reading. Lastly, parameters observed with intravital microscopy were plotted along time of the observation and the area under the curve was assessed.

Assessment of microscopic/macroscopic damage scores

After the intravital microscopy, colon samples from mice were cut open along the mesenteric border and evaluated for macroscopic damage as previously described. Parameters of macroscopic damage scores included edema, hemorrhage, stricture formation, ulceration, fecal blood, mucus, diarrhea, erythema, and adhesion. Each of the parameters was given score of 1 , if present, with exception of erythema and adhesion. Erythema was scored based on length of the area being affected ( 0 , if absent; 1 , if less than $1 \mathrm{~cm} ; 2$, if more than $1 \mathrm{~cm}$ ). Adhesion was scored based on severity ( 0 , if absent; 1 , for mild; 2 , for severe).

Microscopic damage scores were assessed on histological colon samples from chimeric mice. Parameters of microscopic damage scores included cellular infiltration, submucosal edema, damage/necrosis, vasculitis, and perforation. Each of the parameters was scored based on severity ( 0 , if absent; 1 , for mild; 2 , for severe) with exception to vasculitis and perforation, which were given score of 1 if present.

\section{Myeloperoxidase activity}

MPO activity, an index of granulocyte infiltration, on colon samples of chimeric mice was measured as previously described [29]. Briefly, colon samples were homogenized in $0.5 \%$ hexadecyltrimethylammonium bromide phosphate buffer solution ( $\mathrm{pH}$ 6.0). The homogenized colon samples were then centrifuged at $13,000 \times g$ for 3 min and supernatants were placed on 96 well plates. Buffer $(200 \mu \mathrm{l})$ containing $1 \%$ hydrogen peroxide/O-dianisidine dihydrocholoride was 
added to each well. Optical density was measured at a wavelength of $450 \mathrm{~nm}$ for $1 \mathrm{~min}$ at $30 \mathrm{~s}$ interval using a Spectromax Plus microplate spectrophotometer (Molecular Devices, Sunnyvale, CA, USA) and SoftMax Pro software (Molecular Devices).

\section{Histology and chromosome Y staining}

Colon samples from chimeric mice were fixed in $10 \%$ neutral buffered formalin and embedded in paraffin. Sections of $6 \mu \mathrm{m}$ were cut with a Shandon Finesse 325 Microtome (Thermo Scientific, Middletown, VA, USA) and mounted on a colorfrost microslide (VWR scientific, Edmonton, AB, Canada).

For histology, tissue sections were stained with hematoxylin and eosin in accordance with classical methods of histology. Representative photograph sections of each test group were taken using a Retiga EXi camera (Q-imaging, Surrey, BC, Canada) mounted on an Olympus IX81 microscope (Olympus, Melville, NY, USA) and obtained using Volocity 3-D imaging software (Perkin Elmer, Waltham, MA, USA).

Bone marrow reconstitution was assessed by detection of the male (Y chromosome) cells in the female host via in situ hybridization. In short, colonic tissue sections incubated with a CY-3 tagged mouse chromosome Y probe, according to the manufacturer's instruction (Cambio Ltd, Cambridge, UK). Cy3 signals from the slides were visualized using a Fluoview FV1000 confocal microscope (Olympus, Melville, NY, USA) and Olympus Fluoview software.

\section{Statistical analysis}

Statistical comparisons among groups were performed using a one-way analysis of variance followed by the Student-Newman-Keuls test. Data were expressed as mean \pm standard deviation (SD), where a probability ( $p$ value) of $<0.05$ was considered to be statistically significant. $N$ number for each group

$$
\begin{aligned}
& \mathrm{WT}(\mathrm{WT}) \text { control }=8(\text { intrav }=8) \\
& \mathrm{WT}(\mathrm{KO}) \text { control }=9(\text { intrav }=8) \\
& \mathrm{KO}(\mathrm{WT}) \text { control }=7(\text { intrav }=7) \\
& \mathrm{KO}(\mathrm{KO}) \text { control }=7(\text { intrav }=7) \\
& \mathrm{WT}(\mathrm{WT}) \mathrm{DSS}=14(\text { intrav }=9) \\
& \mathrm{WT}(\mathrm{KO}) \mathrm{DSS}=11(\text { intrav }=8) \\
& \mathrm{KO}(\mathrm{WT}) \mathrm{DSS}=16(\text { intrav }=9) \\
& \mathrm{KO}(\mathrm{KO}) \mathrm{DSS}=14(\text { intrav }=8) \\
& \mathrm{WT}(\mathrm{WT}) \mathrm{TNBS}=12(\text { intrav }=10) \\
& \mathrm{WT}(\mathrm{KO}) \mathrm{TNBS}=12(\text { intrav }=11) \\
& \mathrm{KO}(\mathrm{WT}) \mathrm{TNBS}=10(\text { intrav }=10) \\
& \mathrm{KO}(\mathrm{KO}) \mathrm{TNBS}=15(\text { intrav }=15)
\end{aligned}
$$

\section{Results}

Bone marrow reconstitution

Reconstitution of male bone marrow cells injected into female irradiated mice was confirmed by the detection of chromosome Y-stained cells, detected in the colon of DSStreated chimeric mice (Fig. 1a). Chromosome Y staining was present in all infiltrating inflammatory cells but absent in the host derived epithelium, endothelium and enteric neurons (Fig. 1a). As expected, no chromosome Y staining was detected in female mice injected with female bone marrow cells and challenged with DSS (Fig. 1b).

$\mathrm{PAR}_{2}$ expression by non-bone marrow-derived host tissues, play a dominant role in regulating intestinal inflammation in DSS colitis

Four chimeric mouse groups were referred to as WT(WT), $\mathrm{WT}(\mathrm{KO}), \mathrm{KO}(\mathrm{KO})$, or $\mathrm{KO}(\mathrm{WT})$, where $\mathrm{KO}$ represent $\mathrm{PAR}_{2}^{-1-}$ and WT represent $\mathrm{PAR}_{2}^{+/+}$. The genotype inside the bracket indicates the source of bone marrow cells and genotype outside the bracket indicates the recipient mice.

DSS-induced colitis was characterized by loss in body weight and increase in bowel thickness, MPO activity, and damage scores, as compared to water (vehicle) consumption (Fig. 2). DSS treatment led to a significant loss of body weight in all chimeric mouse groups, as compared to their non-inflamed counterparts (Fig. 2a). However, DSS treatment induced a larger loss in body weight in WT(WT) mice, as compared to other chimeric mice groups, and that effect was observed from day 4 until the end of the study (Fig. 2a). The degree of increase in the bowel thickness and MPO activity was significantly reduced in $\mathrm{KO}(\mathrm{KO})$ or $\mathrm{KO}(\mathrm{WT})$ mice, as compared to WT(WT) mice (Fig. 2b, c).
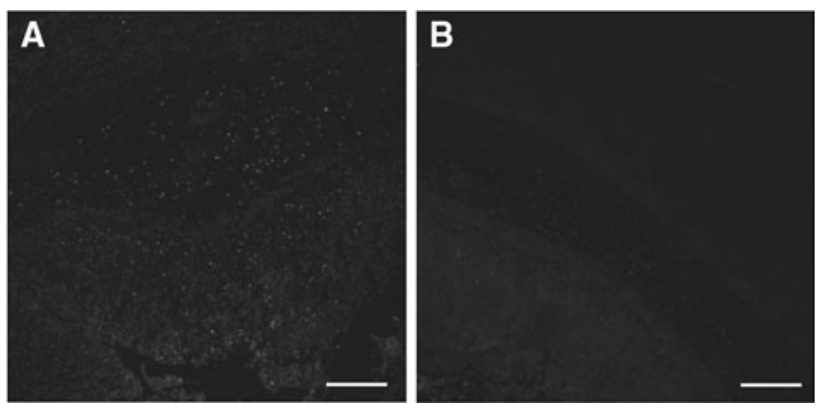

Fig. 1 Chromosome Y staining in colon samples from DSS treated chimeric mice $(\mathbf{a}, \mathbf{b})$. Sections of colon from chimeric mice were hybridized with a CY-3 tagged DNA probe for mouse chromosome $\mathrm{Y}$. Female $\mathrm{PAR}_{2}^{+/+}$mice were injected with either male (a) or female (b) $\mathrm{PAR}_{2}^{+/+}$bone marrow cells. Colitis was induced by giving chimeric mice $2.5 \%$ DSS as a drinking solution for 7 days. Scale bar $100 \mu \mathrm{m}$. PAR Protease-activated receptor, DSS dextran sodium sulfate 

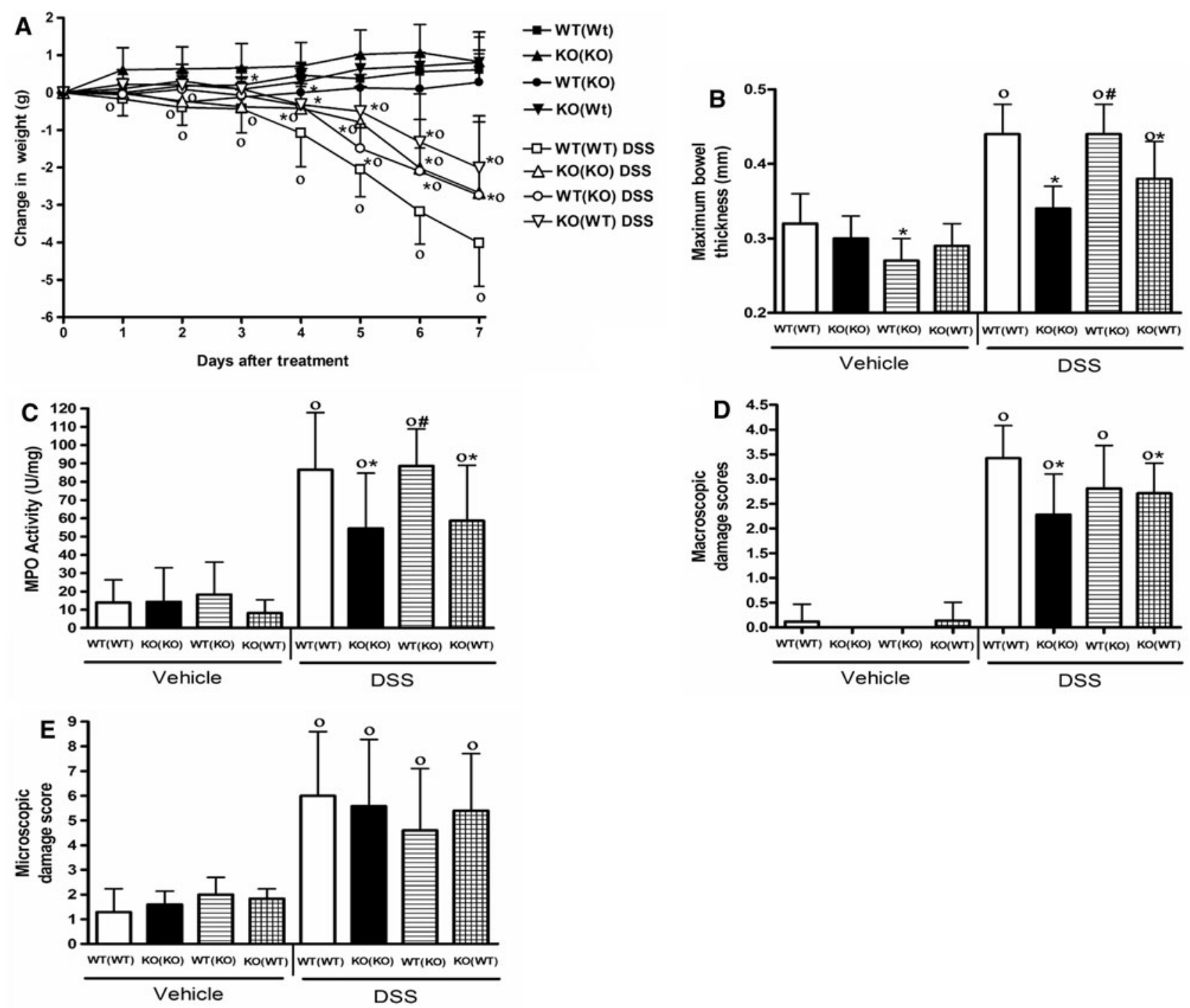

Fig. 2 The effects of $2.5 \%$ DSS-induced colitis on changes in body weight (a), bowel thickness (b), myeloperoxidase ( $M P O)$ activity (c), macroscopic and microscopic damage scores (d, e, respectively) in chimeric mice. Seven days following DSS treatment, colonic tissues from chimeric mice were harvested. Chimeric mice were generated by injecting bone marrow cells from either $\mathrm{PAR}_{2}^{+1+}$ or $\mathrm{PAR}_{2}^{-1-}$ mice (indicated as $\mathrm{WT}$ or $\mathrm{KO}$, respectively) into irradiated recipient mice.

DSS treatment also caused macroscopic damage in the distal colon of mice, characterized by tissue edema, fecal blood, and erythema. Both $\mathrm{KO}(\mathrm{KO})$ and $\mathrm{KO}(\mathrm{WT})$ mice showed significantly reduced macroscopic damage scores (Fig. 2d). Signs of microscopic damage were also observed with DSS treatment, which were characterized by submucosal edema, damage/necrosis of the epithelium and cellular infiltration (Fig. 2e). No significant difference was observed between chimeric mouse groups in terms of microscopic damage scores. Interestingly, while most
Four chimeric mice were used; WT(WT), WT(KO), $\mathrm{KO}(\mathrm{KO})$, or $\mathrm{KO}(\mathrm{WT})$ (groups of 8-10 mice), where the genotype inside the bracket indicates the source of bone marrow cells. OSignificantly different from the control (non-inflamed) group, *significantly different from WT (WT) group treated with DSS, " significantly different from $\mathrm{KO}(\mathrm{KO})$ group treated with DSS $(P<0.05)$. Values are shown as mean \pm standard deviation $(n=7-16)$. DSS dextran sodium sulfate

inflammatory parameters (bowel thickness, MPO, macroscopic damage score) were reduced in chimeric $\mathrm{PAR}_{2}^{-1-}$ mice, whether they express or not $\mathrm{PAR}_{2}$ on bone marrow cells, these parameters were not reduced in mice that did not express $\mathrm{PAR}_{2}$ on bone marrow-derived cells, but express the receptor on other recipient tissues [WT(KO) mice] (Fig. 2). This result shows that in the DSS model, $\mathrm{PAR}_{2}$ deficiency only on bone marrow-derived cells is not sufficient to reduce efficiently inflammatory signs in the colon. 
DSS colitis-induced leukocyte/endothelium interaction is reduced in chimeric $\mathrm{PAR}_{2}^{-1-}$ mice irrespective of the origin of donor bone marrow cells

Intravital microscopy was performed in order to assess changes in flux of rolling leukocytes and adherent leukocytes along the colonic venules of the chimeric mice. DSS treatment induced a significant increase of the area under the curve for the flux of rolling leukocytes and leukocyte adherence in all of the chimeric mice groups as compared to non-inflamed counterparts (Fig. 3). However, DSSinduced increase in rolling and adhesion were significantly reduced in both $\mathrm{KO}(\mathrm{KO})$ and $\mathrm{KO}(\mathrm{WT})$ mice as compared to WT(WT) mice (Fig. 3). No statistical significance was observed between WT(WT) and WT(KO) for the area under curve for leukocyte rolling and adherence. These results show that in the DSS model, the lack of $\mathrm{PAR}_{2}$ expression on bone marrow-derived cells is not sufficient to reduce leukocyte trafficking parameters (rolling and adhesion), but $\mathrm{PAR}_{2}$ deficiency on recipient tissues other than bone marrow cells is necessary to modulate leukocyte trafficking.

Transplantation of bone marrow cells from donor $\mathrm{PAR}_{2}^{-1-}$ mice confers protection from TNBS-induced colitis

As was noted in the DSS model, TNBS-induced colitis led to loss in body weight in chimeric mice (Fig. 4a). However, two groups of mice: $\mathrm{KO}(\mathrm{KO})$ and $\mathrm{WT}(\mathrm{KO})$ lost significantly less body weight as compared to WT(WT) mice from day 2 until the end of the study. For KO(WT) mice, they also lost significantly less body weight than WT(WT) mice, but only at two time-points (days 2 and 4), and for all timepoints this group showed significantly higher weight loss compared to $\mathrm{KO}(\mathrm{KO})$ mice (Fig. 4a). Interestingly, after

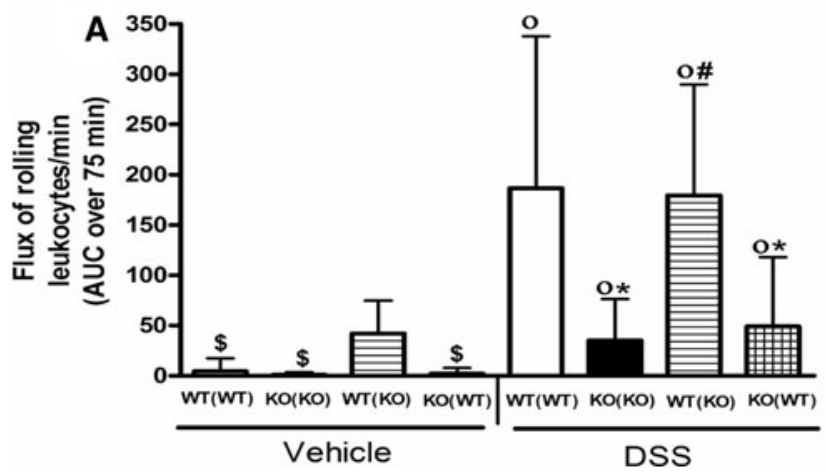

Fig. 3 Changes in flux of rolling leukocytes (a) and adherent leukocytes (b) along the colonic venules of chimeric mice. Mice were treated with $2.5 \%$ DSS or vehicle (water) for 7 days and intravital microscopy was performed. Chimeric mice are designated as indicated in Fig. 2. OSignificantly different from the control (non-
TNBS challenge, $\mathrm{KO}(\mathrm{KO}), \mathrm{KO}(\mathrm{WT})$, and $\mathrm{WT}(\mathrm{KO})$ all showed significantly reduced bowel thickness and MPO activity as compared to WT(WT) mice (Fig. 4b, c). Inhibition of those inflammatory parameters in WT(KO) mice though, was not as profound as in $\mathrm{PAR}_{2}$-deficient mice reconstituted with either $\mathrm{PAR}_{2}$-expressing or $\mathrm{PAR}_{2}$-deficient bone marrow cells (KO(WT) or $\mathrm{KO}(\mathrm{KO})$ groups, respectively) (Fig. 4a-c). TNBS-induced colitis also induced a significant increase in tissue adhesion, edema and erythema, which contributed to the increase in macroscopic damage score in WT(WT) mice (Fig. 4d). $\mathrm{KO}(\mathrm{KO})$, $\mathrm{KO}(\mathrm{WT})$ and WT(KO) mice challenged with TNBS similarly showed reduced macroscopic damage scores as compared to WT(WT) mice. As for microscopic scores induced by TNBS instillation, only $\mathrm{KO}(\mathrm{KO})$ mice showed a significant reduction compared to WT(WT) mice (Fig. 4).

In summary, these studies reveal that expression of $\mathrm{PAR}_{2}$ by either bone marrow-derived cells or recipient tissues is pro-inflammatory in the TNBS model of colitis.

Transplantation of bone marrow cells from donor $\mathrm{PAR}_{2}^{-1-}$ mice reduces leukocyte adherence in TNBSinduced colitis

Leukocyte rolling and adherence along the colonic venules after the development of TNBS-induced colitis was also assessed using intravital microscopy. TNBS challenge significantly increased the area under the curve for the flux of rolling leukocytes in all groups of mice, and none of the different chimera was able to modulate TNBS-induced leukocyte rolling (Fig. 5a). However, leukocyte adherence along the colonic venules was significantly reduced in $\mathrm{KO}(\mathrm{KO}), \mathrm{KO}(\mathrm{WT})$, and $\mathrm{WT}(\mathrm{KO})$ mice as compared to WT(WT) mice (Fig. 5b). These studies reveal that $\mathrm{PAR}_{2}$ expression by either bone marrow-derived cells or recipient tissues regulates leukocyte adhesion and this may represent

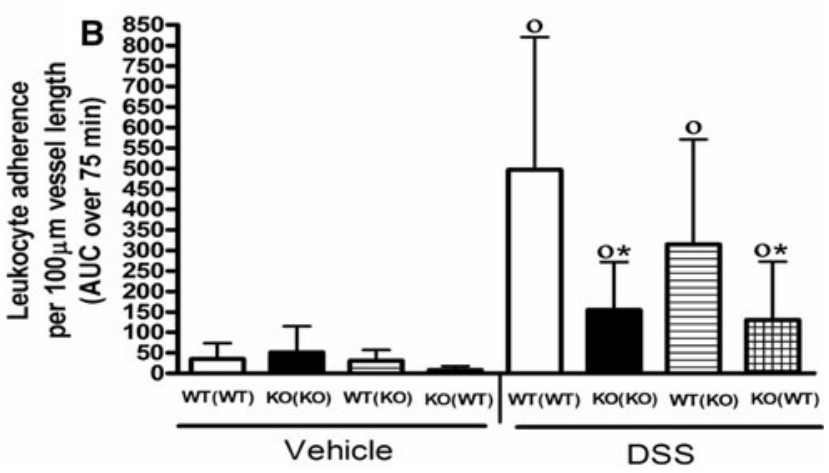

inflamed) group, *significantly different from WT(WT) group treated with DSS, " significantly different from $\mathrm{KO}(\mathrm{KO})$ group treated with DSS, \$significantly different from WT(KO) non-inflamed group $(P<0.05)$. Values are shown as mean \pm standard deviation $(n=7-9)$. $A U C$ Area under the curve, DSS dextran sodium sulfate 

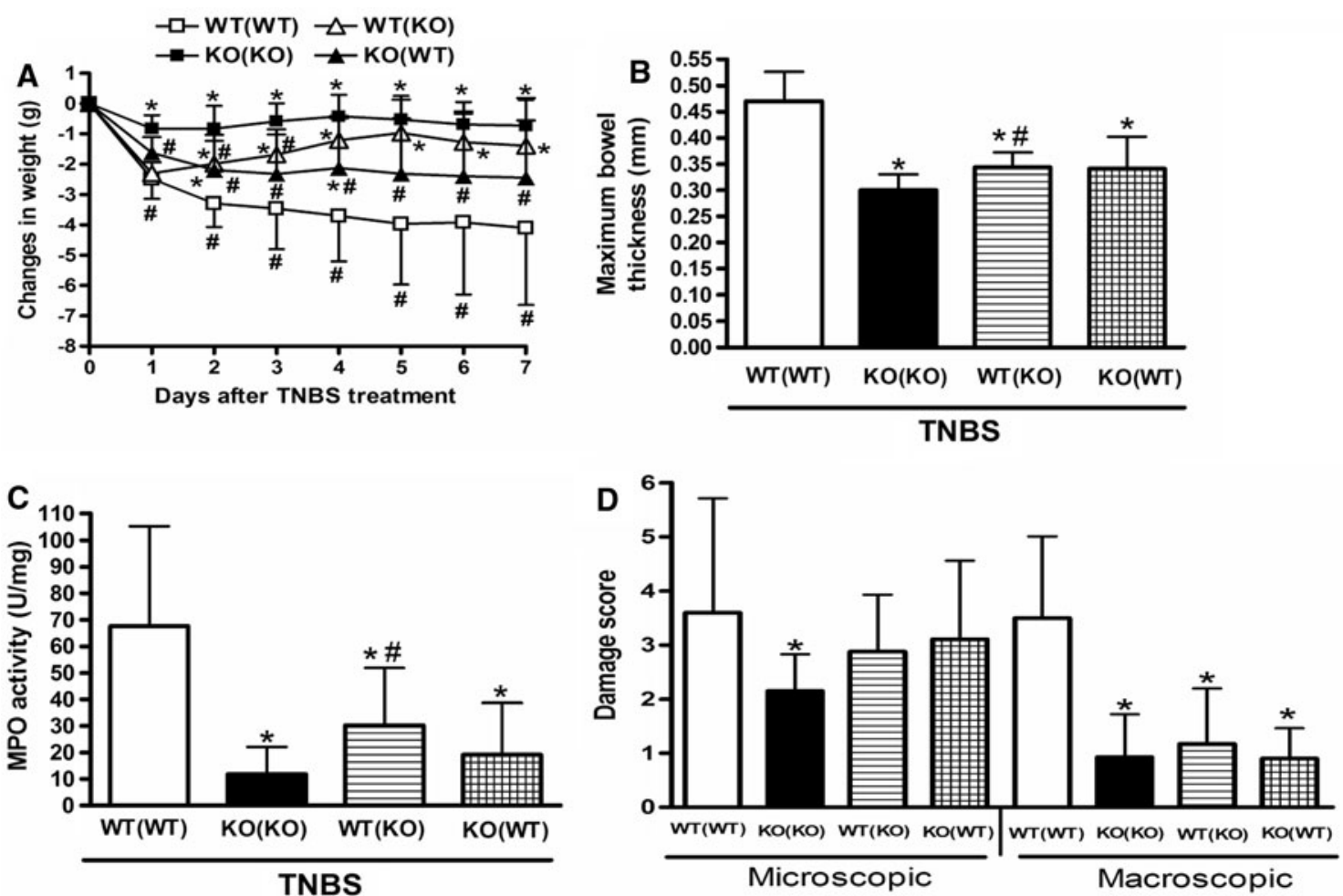

Fig. 4 The effects of TNBS-induced colitis ( $2 \mathrm{mg}$ in $40 \%$ ethanol) on bowel thickness (a), degree of weight loss (b), myeloperoxidase $(M P O)$ activity (c), macroscopic and microscopic damage scores $(\mathbf{d})$ in chimeric mice. Colon tissues were processed for histology 7 days following treatment with TNBS and microscopic damage was

assessed. Chimeric mice are designated as indicated in Fig. 2. *Significantly different from the WT(WT) group treated with TNBS, \# significantly different from the $\mathrm{KO}(\mathrm{KO})$ group treated with TNBS $(P<0.05)$. Values are shown as mean \pm standard deviation $(n=10-15) . T N B S$ trinitrobenzene sulphonic acid

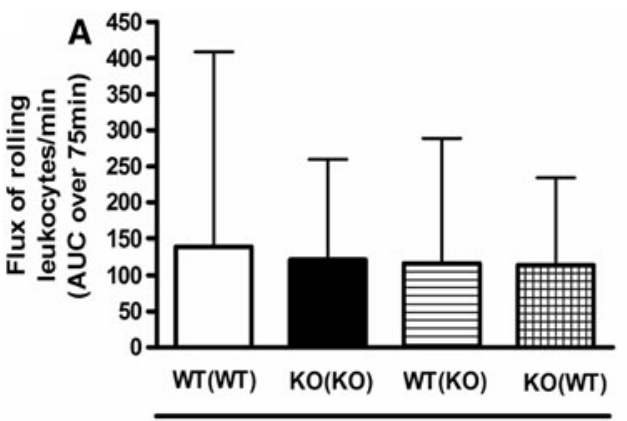

TNBS

Fig. 5 Changes in flux of rolling leukocytes (a) and adherent leukocytes (b) along the colonic venules of chimeric mice. Mice were injected with TNBS ( $2 \mathrm{mg}$ in $40 \%$ ethanol) intrarectally and intravital microscopy was performed 7 days thereafter. Chimeric

a critical mechanism accounting for the pro-inflammatory actions of $\mathrm{PAR}_{2}$ in colitis.

\section{Discussion}

Since the discovery of a role for $\mathrm{PAR}_{2}$ in inflammation [28, 33 ] and the induction or inhibition of inflammatory signs in

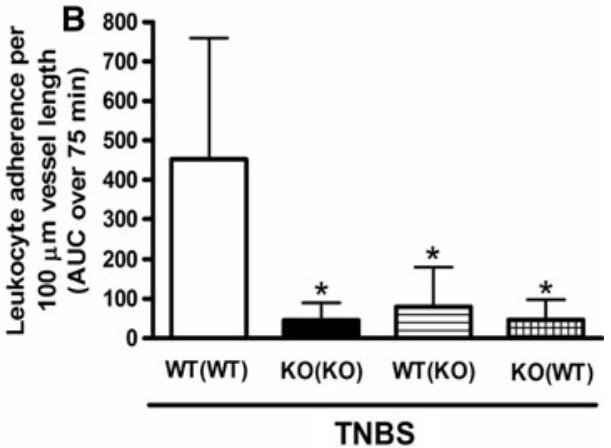

mice are designated as indicated in Fig. 2. *Significantly different from WT(WT) group treated with TNBS $(P<0.05)$. Values are shown as mean \pm standard deviation $(n=10-15)$. AUC Area under the curve, TNBS trinitrobenzene sulphonic acid

response to $\mathrm{PAR}_{2}$ agonists [7, 10, 34, 35], there have been controversies over its role as a pro- or an anti-inflammatory message, depending on the cell types that were activated. The studies outlined here provide evidence that $\mathrm{PAR}_{2}$ activation is a pro-inflammatory signal in the context of animal models of IBD, and provide further understanding on the source of $\mathrm{PAR}_{2}$-expressing cells that are playing or not a critical role in colitis. We showed here that deficiency 
of $\mathrm{PAR}_{2}$ expression on bone marrow-derived cells was not sufficient to protect from DSS colitis, although it seemed sufficient in the other model of IBD: the TNBS model. However, $\mathrm{PAR}_{2}$-deficiency on recipient tissues other than bone marrow-derived cells was sufficient in all models to induce strong resistance to the development of colitis. While the mechanisms that underlie the pro-inflammatory effects of $\mathrm{PAR}_{2}$ activation seemed to involve leukocyte recruitment, $\mathrm{PAR}_{2}$ activation on tissue resident cells rather than leukocytes seemed to play the most critical role in colitis.

$\mathrm{PAR}_{2}$ is widely expressed in almost all cell types present in the gut, including endothelium, epithelium, enteric neurons, fibroblasts, smooth muscle cells, and immune cells [14-17]. Various in vitro studies have shown that the activation of $\mathrm{PAR}_{2}$ in these cells may interplay with the inflammatory process. Studies have indicated that the activation of $\mathrm{PAR}_{2}$ promotes the release of pro-inflammatory cytokines and recruitment of immune cells [36-41], but can also protect from inflammatory insults, through the release by epithelial cells of prostaglandins or neuropeptides by primary afferents. Because the expression of $\mathrm{PAR}_{2}$ is changed in tissues from IBD patients, the idea that $\mathrm{PAR}_{2}$ could contribute to the pathogenesis of the disease has been evoked [42-46]. However, which cellular source for $\mathrm{PAR}_{2}$ expression plays a central role in colitis, and whether this role is pro- or anti-inflammatory depending on the cell types, were still open questions. We focused our attention on the expression of $\mathrm{PAR}_{2}$ on bone marrow-derived cells, as a major role for $\mathrm{PAR}_{2}$ activation on leukocyte recruitment has been suggested by many studies [28, 34, 40, 47]. $\mathrm{PAR}_{2}^{-1-}$ chimeric mice were protected from DSS-induced colitis, irrespective of the source of bone marrow cells. Thus, in DSS challenge, $\mathrm{PAR}_{2}$ expressed on the recipient tissues appears to play a major role in the development of colitis. In TNBS challenge also, we observed that $\mathrm{PAR}_{2}^{-1-}$ chimeric mice were protected from developing colitis irrespective of the source of bone marrow cells. We also observed that $\mathrm{PAR}_{2}^{-1-}$ bone marrow cells conferred protection in $\mathrm{PAR}_{2}^{+/+}$mice challenged with TNBS. Thus, in the TNBS model, $\mathrm{PAR}_{2}$ expressed on both recipient and bone marrow derived cells appears to play a major role in the development of colitis. Different mechanisms involved in the initiation and maintenance of the inflammatory response in these two models may be responsible for these differences. The current concept of pathogenic mechanism of TNBS involves the binding of TNBS to colonic or microbial proteins to generate hapten-protein complex. This complex is then thought to be recognized by the immune system mainly involving macrophages and $\mathrm{T}$ cells that induce inflammatory response [48, 49]. In contrast, the pro-inflammatory effects of DSS is generally thought to be initiated by its cytotoxic effects on the colonic epithelial cells, and therefore loss of epithelial barrier integrity, which leads to an increased exposure of the innate immune system to bacteria and their proteins [49, 50]. The proinflammatory signal thereby initiated leads to the recruitment of leukocytes, mainly neutrophils [49, 51]. Thus, epithelial cell response is generally more extensive for the pathogenic mechanism of DSS-rather than TNBS-induced colitis. The results of the present study could suggest that $\mathrm{PAR}_{2}$ activation plays a severe pro-inflammatory role in the response of intestinal epithelial cells to DSS injury. Indeed, previous studies have shown that $\mathrm{PAR}_{2}$ activation on intestinal epithelial cells can promote the release of IL-8, a potent chemotactic factor for immune cells (especially neutrophils) [41], and increased intestinal epithelial cell permeability [19]. Considering this evidence, the importance of $\mathrm{PAR}_{2}$ on the recipient tissues during the development of DSS-induced colitis may be due, at least in part, to its presence in intestinal epithelial cells. Our results suggest also that $\mathrm{PAR}_{2}$ activation on epithelial cells is a crucial and necessary event to the development of DSS colitis. However, it is also important to point out that $\mathrm{PAR}_{2}^{-1-}$-recipient mice were protected from the development of colitis in both models: DSS and TNBS. TNBSinduced colitis also strongly depends on the loss of epithelial barrier functions, and on the presentation to the innate immune system of luminal microbial antigens, as it has been well established that TNBS colitis did not develop in the absence of colonic flora [52]. The activation of $\mathrm{PAR}_{2}$ on intestinal epithelial cells could also be a crucial event of TNBS-induced colitis. However, our results also show that $\mathrm{PAR}_{2}$ activation on bone marrow-derived cells is a step limiting the event of TNBS colitis. In transmural inflammatory damage such as the ones observed in the TNBS colitis model and that are common in that way to $\mathrm{CD}$ characteristics, regulation of $\mathrm{PAR}_{2}$ activation specifically on bone marrow cells may therefore represent a potential novel form of therapy.

In this study, we have demonstrated a strong correlation between reduction in inflammatory response and a reduction in leukocyte adherence/MPO activity. The process of leukocyte adherence is mainly mediated through interaction between adhesion molecules expressed on the endothelium (intracellular adhesion molecule, ICAM-1, or vascular cell adhesion molecule, VCAM-1) and leukocytes (integrins; composed of alpha and beta subunits) [53, 54]. Previous studies have shown adhesion molecules to mediate the development of colitis. In DSS-induced colitis, antibodies against various adhesion molecules (E-selectin, MAdCAM-1, VCAM-1, and ICAM-1) have been shown to attenuate the intestinal inflammatory responses in animals [32, 55, 56]. In TNBS-induced colitis, antibodies (antiVCAM-1 or anti-MAC-1) or leukocytes (anti-MAC-1) have been shown to decrease tissue damage and monocyte 
infiltration [57, 58]. We and others have also shown that $\mathrm{PAR}_{2}$ plays an important role in up-regulating the expression of adhesion molecules including VCAM-1 and ICAM-1 in inflammatory conditions $[29,38,59]$. Of particular note, these adhesion molecules (with the exception of MAC-1) are commonly found on endothelial cells, which could suggest that $\mathrm{PAR}_{2}$ activation on this cell type constitutes the major signal for leukocyte recruitment. $\mathrm{PAR}_{2}$ activation on endothelial cells has been shown to promote the release of IL- 8 and increase the expression of various adhesion molecules $[36,38,60]$. $\mathrm{PAR}_{2}$ activation on endothelial cells therefore appears as a potential major player to promote leukocyte recruitment upon colitis.

Over recent years, the prospect of using bone marrow transplant as therapy for IBD has been gaining attention. Several case studies have shown improved clinical scores and prolonged periods of remission in IBD patients following autologous bone marrow transplant [61, 62]. The results of our study showed that in both the DSS and TNBS models of colitis, cells derived from recipient may play a greater role in the regulation of intestinal inflammation and tissue damage. Thus, beneficial effects of bone marrow transplant may not be related to the re-setting of $\mathrm{PAR}_{2}$ functions in the patients that were successfully treated by bone marrow transplant.

In summary, $\mathrm{PAR}_{2}$ expressed on cells derived from the recipient rather than bone marrow-derived cells appears to play a prominent pro-inflammatory role in experimental models of IBD. There are numerous possible cell types derived from the recipient that may contribute to the development of colitis including epithelial and endothelial cells. There has been a long debate on whether the main effects of $\mathrm{PAR}_{2}$ in leukocyte recruitment processes are due to the activation of the receptor on endothelial cells or leukocytes. This study clearly shows that in both models (DSS and TNBS), expression of $\mathrm{PAR}_{2}$ on cells other than bone marrow-derived plays a critical role in colitis development and leukocyte recruitment. A partial role to $\mathrm{PAR}_{2}$ expression on bone marrow-derived cells could only be attributed in the context of TNBS colitis, but did not detract from the role of $\mathrm{PAR}_{2}$ on other cell types.

\begin{abstract}
Acknowledgments Thanks to Annie Li for technical assistance with bone marrow transplant. This work was supported by the Canadian Institute for Health Research (to NV), the Foundation Bettencourt Schueller (to NV), the Schlumberger Foundation (to NV), and the Agence Nationale de la Recherche (to NV). EH is supported by the Canadian Institute of Health Research $\mathrm{MD} / \mathrm{PhD}$ funding program.
\end{abstract}

Open Access This article is distributed under the terms of the Creative Commons Attribution Noncommercial License which permits any noncommercial use, distribution, and reproduction in any medium, provided the original author(s) and source are credited.

\section{References}

1. Scaldaferri F, Fiocchi C. Inflammatory bowel disease: progress and current concepts of etiopathogenesis. J Dig Dis. 2007;8:1718 .

2. Wen Z, Fiocchi C. Inflammatory bowel disease: autoimmune or immune-mediated pathogenesis? Clin Dev Immunol. 2004;11: 195-204.

3. Bustos D, Negri G, De Paula JA, Di CM, Yapur V, Facente A, et al. Colonic proteinases: increased activity in patients with ulcerative colitis. Medicina (B Aires). 1998;58:262-4.

4. Cenac N, Coelho AM, Nguyen C, Compton S, ndrade-Gordon P, MacNaughton WK, et al. Induction of intestinal inflammation in mouse by activation of proteinase-activated receptor-2. Am J Pathol. 2002;161:1903-15.

5. Cenac N, Garcia-Villar R, Ferrier L, Larauche M, Vergnolle N, Bunnett NW, et al. Proteinase-activated receptor-2-induced colonic inflammation in mice: possible involvement of afferent neurons, nitric oxide, and paracellular permeability. J Immunol. 2003;170:4296-300.

6. Cenac N, Cellars L, Steinhoff M, ndrade-Gordon P, Hollenberg $\mathrm{MD}$, Wallace JL, et al. Proteinase-activated receptor-1 is an antiinflammatory signal for colitis mediated by a type 2 immune response. Inflamm Bowel Dis. 2005;11:792-8.

7. Fiorucci S, Mencarelli A, Palazzetti B, Distrutti E, Vergnolle N, Hollenberg MD, et al. Proteinase-activated receptor 2 is an antiinflammatory signal for colonic lamina propria lymphocytes in a mouse model of colitis. Proc Natl Acad Sci USA. 2001;98: 13936-41.

8. Raithel M, Winterkamp S, Pacurar A, Ulrich P, Hochberger J, Hahn EG. Release of mast cell tryptase from human colorectal mucosa in inflammatory bowel disease. Scand J Gastroenterol. 2001;36:174-9.

9. Steinhoff M, Buddenkotte J, Shpacovitch V, Rattenholl A, Moormann C, Vergnolle N, et al. Proteinase-activated receptors: transducers of proteinase-mediated signaling in inflammation and immune response. Endocr Rev. 2005;26:1-43.

10. Vergnolle N. Proteinase-activated receptors (PARs) in infection and inflammation in the gut. Int $\mathrm{J}$ Biochem Cell Biol. 2008;40:1219-27.

11. Chignard M, Pidard D. Neutrophil and pathogen proteinases versus proteinase-activated receptor-2 lung epithelial cells: more terminators than activators. Am J Respir Cell Mol Biol. 2006;34:394-8.

12. Dulon S, Cande C, Bunnett NW, Hollenberg MD, Chignard M, Pidard D. Proteinase-activated receptor-2 and human lung epithelial cells: disarming by neutrophil serine proteinases. Am J Respir Cell Mol Biol. 2003;28:339-46.

13. Dulon S, Leduc D, Cottrell GS, D’Alayer J, Hansen KK, Bunnett NW, et al. Pseudomonas aeruginosa elastase disables proteinaseactivated receptor 2 in respiratory epithelial cells. Am J Respir Cell Mol Biol. 2005;32:411-9.

14. Bohm SK, Khitin LM, Grady EF, Aponte G, Payan DG, Bunnett NW. Mechanisms of desensitization and resensitization of proteinase-activated receptor-2. J Biol Chem. 1996;271:2200316.

15. Corvera CU, Dery O, McConalogue K, Gamp P, Thoma M, $\mathrm{Al}$-Ani B, et al. Thrombin and mast cell tryptase regulate guineapig myenteric neurons through proteinase-activated receptors-1 and -2. J Physiol. 1999;517(Pt 3):741-56.

16. D'Andrea MR, Derian CK, Leturcq D, Baker SM, Brunmark A, Ling $\mathrm{P}$, et al. Characterization of protease-activated receptor-2 immunoreactivity in normal human tissues. J Histochem Cytochem. 1998;46:157-64. 
17. Seymour ML, Binion DG, Compton SJ, Hollenberg MD, MacNaughton WK. Expression of proteinase-activated receptor 2 on human primary gastrointestinal myofibroblasts and stimulation of prostaglandin synthesis. Can J Physiol Pharmacol. 2005;83:605-16.

18. Vergnolle N. Clinical relevance of proteinase activated receptors (pars) in the gut. Gut. 2005;54:867-74.

19. Cenac N, Chin AC, Garcia-Villar R, Salvador-Cartier C, Ferrier $\mathrm{L}$, Vergnolle N, et al. PAR2 activation alters colonic paracellular permeability in mice via IFN-gamma-dependent and -independent pathways. J Physiol. 2004;558:913-25.

20. Cenac N, Andrews CN, Holzhausen M, Chapman K, Cottrell G, ndrade-Gordon $\mathrm{P}$, et al. Role for protease activity in visceral pain in irritable bowel syndrome. J Clin Invest. 2007;117:636-47.

21. Cocks TM, Sozzi V, Moffatt JD, Selemidis S. Protease-activated receptors mediate apamin-sensitive relaxation of mouse and guinea pig gastrointestinal smooth muscle. Gastroenterology. 1999;116:586-92.

22. Kawabata A, Morimoto N, Nishikawa H, Kuroda R, Oda Y, Kakehi K. Activation of protease-activated receptor-2 (PAR-2) triggers mucin secretion in the rat sublingual gland. Biochem Biophys Res Commun. 2000;270:298-302.

23. Kawabata A, Kinoshita M, Nishikawa H, Kuroda R, Nishida M, Araki $\mathrm{H}$, et al. The protease-activated receptor- 2 agonist induces gastric mucus secretion and mucosal cytoprotection. J Clin Invest. 2001;107:1443-50.

24. van der Merwe JQ, Moreau F, MacNaughton WK. Proteaseactivated receptor-2 stimulates intestinal epithelial chloride transport through activation of PLC and selective PKC isoforms. Am J Physiol Gastrointest Liver Physiol. 2009;296(6): G1258-66.

25. Vergnolle N, MacNaughton WK, Al-Ani B, Saifeddine M, Wallace JL, Hollenberg MD. Proteinase-activated receptor 2 (PAR2)-activating peptides: identification of a receptor distinct from PAR2 that regulates intestinal transport. Proc Natl Acad Sci USA. 1998;95:7766-71.

26. Cattaruzza F, Cenac N, Barocelli E, Impicciatore M, Hyun E, Vergnolle $\mathrm{N}$, et al. Protective effect of proteinase-activated receptor 2 activation on motility impairment and tissue damage induced by intestinal ischemia/reperfusion in rodents. Am J Pathol. 2006;169:177-88.

27. Nguyen C, Coelho AM, Grady E, Compton SJ, Wallace JL, Hollenberg MD, et al. Colitis induced by proteinase-activated receptor-2 agonists is mediated by a neurogenic mechanism. Can J Physiol Pharmacol. 2003;81:920-7.

28. Vergnolle N. Proteinase-activated receptor-2-activating peptides induce leukocyte rolling, adhesion, and extravasation in vivo. J Immunol. 1999;163:5064-9.

29. Hyun E, Andrade-Gordon P, Steinhoff M, Vergnolle N. Proteaseactivated receptor-2 activation: a major actor in intestinal inflammation. Gut. 2008;57:1222-9.

30. Beck PL, Li Y, Wong J, Chen CW, Keenan CM, Sharkey KA, et al. Inducible nitric oxide synthase from bone marrow-derived cells plays a critical role in regulating colonic inflammation. Gastroenterology. 2007;132:1778-90.

31. Baatz H, Steinbauer M, Harris AG, Krombach F. Kinetics of white blood cell staining by intravascular administration of rhodamine 6G. Int J Microcirc Clin Exp. 1995;15:85-91.

32. Soriano A, Salas A, Salas A, Sans M, Gironella M, Elena M, et al. VCAM-1, but not ICAM-1 or MAdCAM-1, immunoblockade ameliorates DSS-induced colitis in mice. Lab Invest. 2000;80:1541-51.

33. Vergnolle N, Hollenberg MD, Sharkey KA, Wallace JL. Characterization of the inflammatory response to proteinase-activated receptor-2 (PAR2)-activating peptides in the rat paw. $\mathrm{Br} \mathrm{J}$ Pharmacol. 1999;127:1083-90.
34. Cocks TM, Fong B, Chow JM, Anderson GP, Frauman AG, Goldie RG, et al. A protective role for protease-activated receptors in the airways. Nature. 1999;398:156-60.

35. Moffatt JD, Jeffrey KL, Cocks TM. Protease-activated receptor-2 activating peptide SLIGRL inhibits bacterial lipopolysaccharideinduced recruitment of polymorphonuclear leukocytes into the airways of mice. Am J Respir Cell Mol Biol. 2002;26:680-4.

36. Cleator JH, Zhu WQ, Vaughan DE, Hamm HE. Differential regulation of endothelial exocytosis of P-selectin and von Willebrand factor by protease-activated receptors and cAMP. Blood. 2006;107:2736-44.

37. Kong W, McConalogue K, Khitin LM, Hollenberg MD, Payan DG, Bohm SK, et al. Luminal trypsin may regulate enterocytes through proteinase-activated receptor 2. Proc Natl Acad Sci USA. 1997;94:8884-9.

38. Lim SY, Tennant GM, Kennedy S, Wainwright CL, Kane KA. Activation of mouse protease-activated receptor-2 induces lymphocyte adhesion and generation of reactive oxygen species. Br J Pharmacol. 2006;149:591-9.

39. Miike S, McWilliam AS, Kita H. Trypsin induces activation and inflammatory mediator release from human eosinophils through protease-activated receptor-2. J Immunol. 2001;167:6615-22.

40. Shpacovitch VM, Varga G, Strey A, Gunzer M, Mooren F, Buddenkotte J, et al. Agonists of proteinase-activated receptor-2 modulate human neutrophil cytokine secretion, expression of cell adhesion molecules, and migration within 3-D collagen lattices. J Leukoc Biol. 2004;76:388-98.

41. Tanaka Y, Sekiguchi F, Hong H, Kawabata A. PAR2 triggers IL8 release via MEK/ERK and PI3-kinase/Akt pathways in GI epithelial cells. Biochem Biophys Res Commun. 2008;377: $622-6$.

42. Binion DG, West GA, Ina K, Ziats NP, Emancipator SN, Fiocchi C. Enhanced leukocyte binding by intestinal microvascular endothelial cells in inflammatory bowel disease. Gastroenterology. 1997;112:1895-907.

43. Breslin NP, Nash C, Hilsden RJ, Hershfield NB, Price LM, Meddings $\mathrm{JB}$, et al. Intestinal permeability is increased in a proportion of spouses of patients with Crohn's disease. Am J Gastroenterol. 2001;96:2934-8.

44. Schneider J, Jehle EC, Starlinger MJ, Neunlist M, Michel K, Hoppe S, et al. Neurotransmitter coding of enteric neurones in the submucous plexus is changed in non-inflamed rectum of patients with Crohn's disease. Neurogastroenterol Motil. 2001;13:255-64.

45. Vento P, Kiviluoto T, Keranen U, Jarvinen HJ, Kivilaakso E, Soinila S. Quantitative comparison of growth-associated protein43 and substance P in ulcerative colitis. J Histochem Cytochem. 2001;49:749-58.

46. Watanabe M, Yamazaki M, Kanai T. Mucosal T cells as a target for treatment of IBD. J Gastroenterol. 2003;38(Suppl 15):48-50.

47. Lindner JR, Kahn ML, Coughlin SR, Sambrano GR, Schauble E, Bernstein D, et al. Delayed onset of inflammation in proteaseactivated receptor-2-deficient mice. J Immunol. 2000;165: 6504-10.

48. Ballas ZK, Kuppers RC. Naturally occurring antibodies directed to TNBS-modified cell surface but not the trinitrophenyl moiety. J Immunol. 1980;125:1644-9.

49. Wirtz S, Neurath MF. Mouse models of inflammatory bowel disease. Adv Drug Deliv Rev. 2007;59:1073-83.

50. Ni J, Chen SF, Hollander D. Effects of dextran sulphate sodium on intestinal epithelial cells and intestinal lymphocytes. Gut. 1996;39:234-41.

51. Natsui M, Kawasaki K, Takizawa H, Hayashi SI, Matsuda Y, Sugimura K, et al. Selective depletion of neutrophils by a monoclonal antibody, RP-3, suppresses dextran sulphate sodiuminduced colitis in rats. J Gastroenterol Hepatol. 1997;12:801-8. 
52. Videla S, Vilaseca J, Guarner F, Salas A, Treserra F, Crespo E, et al. Role of intestinal microflora in chronic inflammation and ulceration of the rat colon. Gut. 1994;35:1090-7.

53. Radi ZA, Kehrli ME Jr, Ackermann MR. Cell adhesion molecules, leukocyte trafficking, and strategies to reduce leukocyte infiltration. J Vet Intern Med. 2001;15:516-29.

54. Ley K, Laudanna C, Cybulsky MI, Nourshargh S. Getting to the site of inflammation: the leukocyte adhesion cascade updated. Nat Rev Immunol. 2007;7:678-89.

55. Farkas S, Hornung M, Sattler C, Edtinger K, Steinbauer M, Anthuber M, et al. Blocking MAdCAM-1 in vivo reduces leukocyte extravasation and reverses chronic inflammation in experimental colitis. Int J Colorectal Dis. 2006;21:71-8.

56. Hamamoto N, Maemura K, Hirata I, Murano M, Sasaki S, Katsu K. Inhibition of dextran sulphate sodium (DSS)-induced colitis in mice by intracolonically administered antibodies against adhesion molecules (endothelial leucocyte adhesion molecule-1 (ELAM-1) or intercellular adhesion molecule-1 (ICAM-1)). Clin Exp Immunol. 1999;117:462-8.

57. Sans M, Panes J, Ardite E, Elizalde JI, Arce Y, Elena M, et al. VCAM-1 and ICAM-1 mediate leukocyte-endothelial cell adhesion in rat experimental colitis. Gastroenterology. 1999;116:874-83.

58. Palmen MJ, Dijkstra CD, van der Ende MB, Pena AS, Van Rees EP. Anti-CD11b/CD18 antibodies reduce inflammation in acute colitis in rats. Clin Exp Immunol. 1995;101:351-6.

59. Seeliger S, Derian CK, Vergnolle N, Bunnett NW, Nawroth R, Schmelz M, et al. Proinflammatory role of proteinase-activated receptor-2 in humans and mice during cutaneous inflammation in vivo. FASEB J. 2003;17:1871-85.

60. Seitz I, Hess S, Schulz H, Eckl R, Busch G, Montens HP, et al. Membrane-type serine protease-1/matriptase induces interleukin6 and -8 in endothelial cells by activation of protease-activated receptor-2: potential implications in atherosclerosis. Arterioscler Thromb Vasc Biol. 2007;27:769-75.

61. Oyama Y, Craig RM, Traynor AE, Quigley K, Statkute L, Halverson A, et al. Autologous hematopoietic stem cell transplantation in patients with refractory Crohn's disease. Gastroenterology. 2005;128:552-63.

62. Burt RK, Traynor A, Oyama Y, Craig R. High-dose immune suppression and autologous hematopoietic stem cell transplantation in refractory Crohn disease. Blood. 2003;101:2064-6. 